\title{
SWOT Analysis for Business Strategies : A Case of Azka Syahrani in Muslim Fashion Industry
}

\author{
A R Fauzi ${ }^{1}$, U Cariawan ${ }^{2}$ \\ ${ }^{1,2}$ Faculty of Economic and Business, Universitas Indonesia, Jakarta, Indonesia \\ 1atikarff@gmail.com
}

\begin{abstract}
Small and Medium Micro Enterprises effects significantly in economic growth in Indonesia due to the large market potential. Small and medium-sized enterprise have ability to move and decide quicky, according to that, small and mediumsized enterprises need to recognize the strategy to maintain their sustainability. This study aims to understand the business strategy of AzkaSyahrani by using SWOT analysis. The SWOT matrix was used to determine the actions of AzkaSyahrani to attain market share in Indonesia and also to understand and analyze the business environment. SWOT reveals critical factors that if addressed properly, can be necessary to the development of a strategic plan. SWOT is used to know external and internal factor for Muslim fashion industry. The analysis of the external environment in the development of muslim fashion industry aims to evaluate trends and events that are beyond the control of crafters/entrepreneurs, like rapid growing of social media as a marketing tools and focuses on determining key factors that become opportunities and challenges for AzkaSyahran while the analysis of internal environment of the muslim fashion industry is used to determine the ability of artisans in developing the business such that that it can move forward. It also can be used developing a sustainable competitive advantage; identifying opportunities and threats; and providing opportunities for productive co-operation with other companies. In additon this conducted with qualitiative method and an in-depth interview with the owner of the Azka Syahrani. The research corroborobates that the AzkaSyahrani conducts their business in a way that consumer consider its products as a way to represent themselves.
\end{abstract}

Keywords: SWOT, Muslim Fashion, Azka Syahrani

\section{INTRODUCTION}

Indonesia's Small and Medium Enterprises (SMEs) sector is currently grappling to overcome a host of tough new challenges. ccording to the Cooperatives and SME Ministry, in 2014, Indonesia had 57.9 million SMEs which contributed to around 58.92\% of the country's GDP and absorbed $97.30 \%$ of the country's workforce [1].

SMEs have big influence because it have the ability to move and decide quickly, the dynamic charcteristics of SME and also the ability to innovate. SMEs become one of the sectors that supported and developed by governement from technology, financial and materials. Government wants to create a capable SME that someday will become Indonesia's 
pillar of economy. The empowerment that done by Government to SME are to create jobs, to increase development in every region and to reduce poverty. However, there are some traditional problems that SME face like lack of cash, no plan or strategies to sustaining or establishing their business, lack of managerial capability, and regulatory burdens. It is important, especially for small company to know their ability and how they could use it to sustain in the busines, but most of SME think that their company did not big enough to perform data and usually relay on some big customer.

According to data from BPS (2013), the number of companies engaged in the fashion sector reached 1,107,955 units. Around 10\% of them are large companies, $20 \%$ are medium enterprises and $70 \%$ are small enterprises. Of the 750,000 SMEs engaged in the clothing sector in Indonesia, around $30 \%$ of them are muslimwear producers, with large companies occupying $40 \%$, while small and medium enterprises each occupy $30 \%$ respectively of the market [1].

One of the muslimwear producer in Indonesia is Azka Syahrani that was once built to empower women around the neighbourhood. Each of Azka Syaharani products is embroidered by hand and have unique characteristics. Given the uniqueness of the Azka Syahrani products, we are interested in examining their business strategy deeply which is very important because Azka Syahrani is almost fall for bankruptcy. There are several major problems that faced by Azka Syahrani, like poor management system, heavily relied on their big customer and financial problems. We will conduct a strategy based on internal conditions and external environment of Azka Syahrani.

The role of strategy can be studied by various academics and practitioners because itrewuires a rational decision such that strategic planning can be done on SMEs [2]. Business strategies can be understood more detail via SWOT analysis. The object of this paper is AzkaSyahrani - one of the small and medium-sized enterprises in the Muslim fashion industry. This research analyzesexternal and internal analysis environment to examine which part can be developed by enterprises to yield better returns and how to reconstruct it. The result of this study are expected to be useful for SMEs, such as Azka Syahrani, in developing business strategies.

\section{LITERATURE REVIEW}

Developing countries value small and medium enterprises (SMEs) for several reasons, such as their potential to grow into larger, more productive units; their ability to invest and adopt new technologies and their ability to adapt to new economic circumstances [3].

The promotion of Micro and Small Enterprises as a strategy to promote employement in rural areas has received considerable recent attention in Indonesia [4]. Different definitions of SMEs emerge because the individual of economic in certain countries can affect the definition itself. In indonesia In Indonesia, SMEs possess the economic strength required to stabilize the economy. Most countries accept that the number of employees in SMEs is a common measurement for defining SMEs. Various opinions are used regarding the size of SME measurement criteria. In Indonesia, the criteria to measure SMEs are their assets and turnovers $[2]$.

The strategic situation analysis is used to understand and analyze the business environment. Generally, the academic sector agrees on its definition. It is primarily based on assessing individual components and characteristics of the internal and external environment of enterprises by using methods analyzing external and internal environments, so-called strategic analyses [5]. Šulák et al (2005) categorize business environment as the external environment 
whose parts are the macro environment and the meso environment of the enterprise and the internal environment including the enterprise analysis and the micro environment meaning the internal sources of the enterprise.

The dynamics of internal sources supports the growth of enterprises and helps create their sustainable competitive advantage. It is necessary to examine the structure and content of the individual analyses since some do not have a universal character and therefore cannot be used in a unified manner especially when considering the sector differentiation of enterprises and their size categorization. It is probable that the future development of enterprises will be dictated by new trends in the area of strategic planning cycle, strategic methods and tools of strategic management, as well as techniques of implementing set strategies in enterprise practice [5]. The strategy itself can be created by internal strengths and weaknesses and external opportunities and threats [2]. The strategy is regarded as an important process for businesses [2]. External conditions and internal environmental factors are terms of strategic management in the relationship between a company and the environment [6].

Environmental analysis is important for developing a sustainable competitive advantage; identifying opportunities and threats; and providing opportunities for productive co-operation with other companies. A review of the literature reveals that different approaches and techniques were used for the analysis of macro environment [6]. The model examined in the present study is PESTEL (Political, Economic, Socio-cultural, Technological, Environment and Legal) analysis. PESTEL analysis has two basic functions for a company. The first is that it allows identification of the environment within which the company operates. The second basic function is that it provides data and information that will enable the company to predict situations and circumstances that it might encounter in future [6]. PESTEL analysis is therefore a precondition analysis, which should be utilized in strategic management [6].

For internal analysis, researcher used Value Chain analysis. Value chain is a description of the activities undertaken by the company to plan, create, market, deliver and support the resulting product. Value chain of a company and describes the history, strategy, approach taken to implement the basic economic strategy and activities [7].

SWOT reveals critical factors that if addressed properly, can be necessary to the development of a strategic plan. Other critical aspects for a strategic plan include the determination of a Vision and Mission for the organization [8]. SWOT can be described as a tool for strategic planning into those categories [2]. The evaluation confirms that SWOT is an effective business tool. It is simplicity of use and extraction of critically significant business factors for the company, allows proper engagement, usage and support. Thus, SWOT can be applied successfully to SMEs despite issues such as limited resources, available time, and moderate business analytical business competencies [8].

The SWOT matrix is a model for formulating alternative strategies that are combined with internal and external company data. The alternative strategies are (1) SO power strategy/ opportunity/ strategy; (2) WO strategies/ weaknesses/ opportunities/ strategies; (3) WT's strategy of weakness/ threat/strategy and (4) strategy of force threat/strategy ST. The steps in developing the SWOT matrix are detailed below :

Table 1. SWOT Matrix

\begin{tabular}{ccc}
\hline & Strenghs (S) & Weakness (W) \\
\hline Opportunities $(\mathrm{O})$ & Strategy S-O & Strategy W-O \\
Threats $(\mathrm{T})$ & Strategy S-T & Strategy W-T \\
\hline
\end{tabular}

Source : Rangkuti (2000) in Malina (2018) 


\section{METHOD}

This study is analyzed qualitatively. The data has been collected through observation at the company unstructured interviews with Owner Azka Syahrani and documentation.This research is based on a case study of a small and medium-sized enterprise in Muslim fashion industry in Indonesia..The participant were chosen based on their knowledge about the whole business process in the company. Qualitative research does not produce anepistemological paradigm (related to origin, trait and character) in particular but is a classical scientific process that comprises confronting predicted influences with observed phenomena in a holistic environment [2]. Qualitative research methods for the interpretation and analysis of texts already existing or transcribed from talk, observation or video can be used to explore meanings of social and bodily phenomena as how and why human beings act as they do, within their natural context [9]. Researchers use techniques for colecting data with obervation and note-taking directly on the research object. The observation and interview consist of issues that related to external and internal environment based on the research aims. The issues explored in the interview and observations are concerned with business strategy that linked with internal sources and external environment. After doing the interview and observtion, verbal transcript were made and anlyzed with content analysis.

\section{RESULT AND DISCUSSION}

The Internal and external environmental factors in this research will be identified on the basis of the findings in the field, thereby covering the potential factors [2]. The internal analysis used VALUE CHAIN and summarized in a table that consists of 4 aspects (human resources, marketing, finance and production.

The analysis of the external environment in the development of muslim fashion industry aims to evaluate trends and events that are beyond the control of crafters/entrepreneurs and focuses on determining key factors that become opportunities and challenges for Azka Syahrani. The analysis of external environment is generally observed from several aspects, such as the political, economi, social, cultural and technological aspects.

Table 2. External Environmental Analysis

\begin{tabular}{|c|c|c|c|}
\hline No & Aspects & Factors & Opportunities/Threats \\
\hline 1 & Politics & $\begin{array}{l}\text { - The political situation in } \\
\text { Indonesia that cause uncertainty. } \\
\text { - } \quad \text { Religion Issues }\end{array}$ & Threats \\
\hline 2 & Economic & $\begin{array}{ll}\text { - } & \text { Indonesia's large muslim } \\
& \text { population (potential market) } \\
\text { - } & \text { Growth of middle class }\end{array}$ & Opportunities \\
\hline 3 & Social & $\begin{array}{ll}\text { - } & \text { Indonesians prefer foreign product } \\
\text { - } & \text { Easy to plagiarism product }\end{array}$ & Threats \\
\hline 4 & Technology & $\begin{array}{l}\text { - Rapid growing of technology (the } \\
\text { use of social media and website) }\end{array}$ & Opportunities \\
\hline 5 & Environmental & $\begin{array}{l}\text { - Government conduct an exhbition } \\
\text { peridically for SMEs so they can } \\
\text { introduce their product }\end{array}$ & Opportunities \\
\hline
\end{tabular}


The analysis of the internal environment of the muslim fashion industry is used to determine the ability of artisans in developing the business such that that it can move forward. Internal environmental analysis is based on factors that are originally from within the company itself and can generally be controlled by the company. The internal environment is the process of identifying the factors that become the strengths and weaknesses of a company. The internal environment analysis is using Value Chain analysis, with the detail below :

Table 3. Value Chain Analysis

\begin{tabular}{|c|c|c|c|c|c|c|}
\hline \multicolumn{6}{|c|}{ FIRM INFRASTRUCTURE } & \\
\hline \multicolumn{2}{|c|}{$\begin{array}{l}\text { Administration } \\
\text { and General Affair }\end{array}$} & \multicolumn{4}{|c|}{ General Management $f$ the business unit as entity } & \\
\hline \multicolumn{2}{|c|}{ Human Resource } & \multicolumn{4}{|c|}{ Recuriting, make job description, and rewarding } & \\
\hline \multicolumn{2}{|c|}{$\begin{array}{l}\text { Product and } \\
\text { Development } \\
\text { Technique }\end{array}$} & \multicolumn{4}{|c|}{$\begin{array}{l}\text { Developing products or service and technology } \\
\text { needed. }\end{array}$} & $=$ \\
\hline \multicolumn{2}{|l|}{ Procurement } & \multicolumn{4}{|c|}{ Acquire necessary inputs to value adding activties. } & Sales- \\
\hline $\begin{array}{l}\text { Inbound } \\
\text { Logistics }\end{array}$ & Oper & tion & $\begin{array}{l}\text { Outbound } \\
\text { Logistics }\end{array}$ & $\begin{array}{l}\text { Sales and } \\
\text { Marketing }\end{array}$ & Service & unt \\
\hline $\begin{array}{l}\text { input } \\
\text { Receive, } \\
\text { Store and } \\
\text { distributing } \\
\text { inputs. }\end{array}$ & $\begin{array}{l}\text { Trans } \\
\text { input } \\
\text { the pr }\end{array}$ & $\begin{array}{l}\text { forms } \\
\text { into } \\
\text { oducts }\end{array}$ & $\begin{array}{ll}\text { Distribute } & \\
\text { product } & \text { or } \\
\text { service } & \text { to } \\
\text { customer. } & \end{array}$ & $\begin{array}{l}\text { Provide ways } \\
\text { for customer } \\
\text { to buy } \\
\text { product. }\end{array}$ & $\begin{array}{l}\text { Enhance } \\
\text { the value } \\
\text { of } \\
\text { products or } \\
\text { services } \\
\text { sold. }\end{array}$ & \\
\hline
\end{tabular}

Source : Survey Results (2018)

Table 3 shows that Azka Syahrani already divide the function from each division. In human resources weaknesses are observed in Azka Syahrani which should be improved. In terms of decision making, it still dominated by the owner and professionalism is still low. In marketing, Azka Syahrani just developed online marketing, by re-decorate their website and social media. Azka Syahrani also provide many ways for customer to buy their products.

Production by Azka Syahrani is included as strength of the business, because the maximum capacity that can reach 5000 pieces a day. Production made to order is considered a strength because the resulting products will always be sold. Financing in Azka Syahrani is very limited, only from the sales and the owner. 
Table 4. Internal Environmental Analysis

\begin{tabular}{|c|c|c|c|}
\hline No & Aspect & Factors & Strenght/Weakness \\
\hline 1 & $\begin{array}{l}\text { Human } \\
\text { resource }\end{array}$ & $\begin{array}{l}\text { - Decission dominated by the } \\
\text { owner } \\
\text { - } \quad \text { Lack of professionalism }\end{array}$ & Weakness \\
\hline 2 & Marketing & $\begin{array}{l}\text { - User-Friendly Website and } \\
\text { Social Media }\end{array}$ & Strengh \\
\hline 3 & Finance & - Own capital is very limited & Weakness \\
\hline 4 & Production & $\begin{array}{l}\text { - } \quad \text { Production by order } \\
\text { - } \quad \text { Big capacity of production }\end{array}$ & Strengh \\
\hline
\end{tabular}

Table 5. SWOT Analysis

\begin{tabular}{|c|c|c|}
\hline & $\begin{array}{ll}\text { Strenghs (S) } \\
\qquad \quad \text { User friendly website } \\
\text { and interactive social } \\
\text { media } \\
\text { - } \quad \text { Many ways provided } \\
\text { to buy the prodcust } \\
\text { - } \begin{array}{l}\text { Big capacity of } \\
\text { production }\end{array}\end{array}$ & $\begin{array}{ll}\text { Weakness }(\mathbf{W}) \\
\text { - } \\
\text { Decision making stil } \\
\text { dominated by owner } \\
\text { - } & \text { Lack of } \\
& \text { professionalism } \\
\text { - } & \text { Capital is very } \\
& \text { limited }\end{array}$ \\
\hline $\begin{array}{ll}\text { Opportunities (O) } \\
\text { - } & \text { Large population of } \\
& \text { moslem in Indonesia } \\
\text { - } & \text { Growth of Middle Class } \\
\text { - } & \text { Rapid Growing of } \\
& \text { technology } \\
\text { - } & \text { Government support in } \\
\text { exhibition } \\
\text { - } \\
\text { Laws that protect and } \\
\text { ensure the growth of } \\
\text { SME }\end{array}$ & $\begin{array}{l}\text { Strategy S-O } \\
-\quad \text { Increase the use of } \\
\text { social media through } \\
\text { endorsing } \\
\text { - Following the } \\
\text { exhibition that conduct } \\
\text { by the government }\end{array}$ & $\begin{array}{ll}\text { Strategy W-O } \\
\bullet \quad \text { Management by } \\
\text { following } \\
\text { government-provided } \\
\text { SME programs } \\
\bullet \quad \text { use the provision of } \\
\text { funding from syariah } \\
\text { institution }\end{array}$ \\
\hline $\begin{aligned} \text { Threats } & (\mathbf{T}) \\
\text { - } & \text { Political situation in } \\
& \text { indonesia tha cause } \\
& \text { uncertainty } \\
\text { - } & \text { Religion issues } \\
\text { - } & \text { Plagiarism of products }\end{aligned}$ & $\begin{array}{l}\text { Strategy S-T } \\
\qquad \text { Business owner } \\
\text { becoming a resource } \\
\text { person to introduce } \\
\text { Azka Syahrani } \\
\text { products }\end{array}$ & $\begin{array}{l}\text { Strategy W-T } \\
\text { - } \\
\text { Products of Azka } \\
\text { Syahrani should be } \\
\text { processed HAKI } \\
\text { such no duplication } \\
\text { or imitation or the } \\
\text { products }\end{array}$ \\
\hline
\end{tabular}

Source : Survey Results (2018) 


\section{CONSLUSION}

\subsection{Conslusion}

Azka Syahrani is an SME that has managed to last after times of bankcrupty. The difficulty level of product, the handmade of emboridery and rare design attracts consumer. But if they developed their strategy based on SWOT that already explained above it will make their business sustainable. If they managed to make the working environment become more professional it will make their production more efficient. Azka Syahrani's ability to succed in the Indonesian market because they already have loyal customer and also distribution channel that spread all over Indonesia.

\subsection{Limitation}

The data based on interview and observation only due to the time limit and rules from Azka Syahrani owner.

\section{REFERENCES}

[1] Global Business Guide Indonesia, "Indonesia SMEs Business," Global Business Guide Indonesia, 2016. [Online]. Available: http://www.gbgindonesia.com/en/main/why_indonesia/2016/indonesia_smes_increase d_government_support_to_overcome_challenges_11603.php.

[2] E. Maulina, "SWOT Analysis for Business Strategies : A Case of Virage Awi in the Bamboo Craft Industries, Bandung, Indonesia," Rev. Integr. Bus. Econ. Res., vol. 7, no. 2, pp. 213-225, 2018.

[3] A. Berry, E. Rodriguez, and H. Sandee, "Small and Medium Enterprise Dynamics in Indonesia,” Bull. Indones. Econ. Stud., vol. 37, no. 3, pp. 363-384, Dec. 2001.

[4] S. P. Singh, R. G. Reynolds, and S. Muhammad, "A Gender-Based Performance Analysis of Micro and Small Enterprises in Java, Indonesia," J. Small Bus. Manag., vol. 39, no. 2, pp. 174-182, Apr. 2001.

[5] J. Straková, "Strategic analysis methods and their influence on stability and development of small and medium-sized enterprises in the Czech Republic," Stud. Commer. Bratisl., vol. 10, no. 38, pp. 196-214, Sep. 2017.

[6] I. Yüksel, "Developing a Multi-Criteria Decision Making Model for PESTEL Analysis,” Int. J. Bus. Manag., vol. 7, no. 24, Nov. 2012.

[7] M. E. Porter, "The five competitive forces that shape strategy," Harv. Bus. Rev., vol. 86 , no. 1 , pp. 78-93, 2008.

[8] Tenney D J and Marquis, "SWOT as a Constructive Predictor for Business Success of SMEs: A Case Study," in Proceedings For The Northeast Region Decision Sciences Institute (NEDSI), 2017, pp. 1014-1023.

[9] K. Malterud, K. Hamberg, and S. Reventlow, "Qualitative methods in PhD theses from general practice in Scandinavia," Scand. J. Prim. Health Care, vol. 35, no. 4, pp. 309-312, Oct. 2017. 